\title{
Morphosyntactic Analysis of Onitsha Personal Names
}

\author{
Chika Obiageli Ezeudo \\ Department of Linguistics, Nnamdi Azikiwe University, Awka, Nigeria \\ Sopuruchi Christian Aboh* \\ Department of Linguistics, Igbo and other Nigerian Languages, University of Nigeria, Nsukka, Nigeria \\ Kalu Mba Idika \\ Department of Linguistics, Igbo and other Nigerian Languages, University of Nigeria, Nsukka, Nigeria
}

\begin{abstract}
This study examines Onitsha personal names (OPN) from a morphosyntactic perspective. The major objective of this study is to examine the syntactic and morphological structure of some OPN. Specifically, the study seeks to ascertain the morphological processes and the relation in the internal structures of the morpheme that are combined to form the names. A sample of 250 names for both male and female were used for the analysis. The data were obtained from a list of names in schools, men and women religious associations. Oral interviews were conducted with native speakers in order to get clarifications as it concerns the meaning of the names. The roots, stems, and affixes of the names were analysed using the descriptive approach and applying the word formation rules. The findings reveal the following: that most of the morphological processes in the formation of OPN are predominantly clipping, prefixing and suffixing in a hierarchical manner, such that the meaning of the names are predictable from their structural components and most of these names are derived from clauses by desententialisation process; the philosophy behind the names are often lost due to clipping; OPN at sentential level can function as statements, interrogatives, or imperatives, commands; the morphological components in terms of size, length or shape can be monomorphemic, dimorphemic, trimorphemic and polymorphemic. Structurally, they can be single stem, compound or complex.
\end{abstract}

Index Terms — morphology, syntax, anthroponyms, Onitsha, onomastics

\section{INTRODUCTION}

Names are given in particular languages whose morphology, syntax and semantic inform their meaning to great extent (Batoma, 2006). This implies that understanding personal names hinges on taking a critical look at the internal structures of the word(s) and the syntactic structure that constitute the name besides sociolinguistic, sociocultural, historical and ethno-linguistic domains. The study of personal name is important in understanding the culture, norms, and values, and circumstances behind the birth of individuals. It further foregrounds the place of proper names as a major etiquette of the society and understanding of this is necessary for a peaceful co-existence in the society.

Onomastics is an area that studies names in all aspects. In the most precise terminology; a set of personal names is called anthroponyms and its study is called anthroponymy. Onitsha indigenes attached much importance to names and naming practices. The knowledge about Onitsha names give insight into Onitsha, culture, philosophy, thoughts, environment, religion, language and culture. Many scholars have written on the social, cultural importance of names (see Onukawa, 2000; Agyekum, 2006; Ahamefula et al. 2019; Ikotun, 2013; Akinola, 2014) but little attention is given to the morphosyntactic analysis of Onitsha personal names to the best of the researchers' knowledge. A related linguistic structural analysis of personal names is Eze, Aboh and Eze's (2020) research where they explored the linguistic formation patterns of anglcised traditional Yorùbá anthroponyms. Their research focused mainly on phonological features of anglicised Yorùbá personal names. This study therefore seeks to add another dimension to the study of names by using a morphosyntactic approach to analyse Onitsha personal names, which is a variety of the Standard Igbo language. This study is important because since the philosophy behind some names are lost due to truncation, studying Onitsha personal names (henceforth, OPN) from a morphosyntactic perspective helps to trace back the initial structures of OPN.

Folklores on the origin of Onitsha reveal that Onitsha has a close contact with Igala and Edo through Igweze Chima. This necessitated the borrowing of a list of names from the town. Linguists use the term borrowing and loanword to refer to instances in which one language takes a lexical expression from another language (Haspelmath, 2008). Onitsha is a town in Anambra State, Nigeria.

\footnotetext{
* Corresponding author's email: sopuruchi.aboh@unn.edu.ng
} 
The objectives of this study are to identify the morphological components of OPN and to analyse the syntactic functions and structures of OPN. This is a qualitative study which involves the morphosyntactic analysis of Onitsha personal names. Insights from morphological and syntactic principles are used to interrogate the data. Here, morphological analysis is seen as the syntax of morpheme, and a complex word is seen as a concatenation of morphemes. (Aronoff, 1976; Yule, 2020). Onomastics has influenced the recovering and reconstruction of many heritages. In the words of Batoma (2006, p. 2), "a major trend in African studies today consists of using traces of African culture embedded in African names and naming practices to recover or reconstruct Africa heritage". In addition to this, personal names can be grouped with reference to their formation which include those of one word or element and those made up of two elements; compounds. This classification has linguistic underpinning. The type of classification crucial to the study is the one with linguistic orientation.

The data for the study were obtained from a list of names in schools, men and women religious associations who are of Onitsha origin. In all, the researchers randomly sampled 250 personal names over a period of four months. After collecting the names, the researchers used inductive and creative synthesis approach to data analysis to categorise and code the personal names under the right morphological and syntactic divisions. The researcher also interacted with the elders, youths of Onitsha indigenes to gather the story that portrays the philosophy behind the names. This was useful because it helped the researcher to get the underlying personal morphological and syntactic structures of the names since they are no more in their original form due to the short forms that are used in this contemporary time.

\section{Theoretical Perspectives}

Onukawa (2000) maintains that the core values of a people are better propagated in the native language. He further explains that the Igbo values are seriously threatened and an achievement on its propagation should be made more and better via a very important component of the language, therefore, Igbo should return to the traditional Igbo personal names, and let the names serves as vehicles for the propagation of Igbo core values since the traditional names are very rich in culture content.

In line with the above, Batoma (2000) opines that names are given in particular languages whose morphology, syntax and semantics inform their meaning to a great extent. This implies that understanding names (personal names) hinges on taking a critical look at the internal structure of the word(s) and the syntactic structure that constitute the name besides sociolinguistics, sociocultural, historical and ethno-linguistics domain.

Mbhele (2006) argues that names convey important socio-cultural information, they are analysable into syntactic components such as phrase types and sentence types she studies Sesotho names. According to Anderson (1992), the ideas of morpheme are as follows: Morpheme are homogeneous and indivisible atomic units of linguistic form; each morpheme in a given phonological represented by exactly one morph and each morph represents exactly one morpheme and they are arranged into a structure of immediate constituent, which yields a sort of phrase marker as the analysis of a word structure. In addition, Anderson notes that since the function of derivation is to construct new words of this sort, it follows all derivation must take place prior lexical interpretation. On the other hand, inflectional operation refers to a morphosyntactic representation as well as to a stem, so all genuinely inflectional operation must take place after lexical interpretation. In the word of Halle (1973) word formation Rules (WFRs) are therefore necessary to specify how morphemes are to be arranged.

The paper analyses OPN by looking at their morphological and syntactic components. The morphological component deals with the internal structure of the individual morphemes that constitute the names. This helped to identify the word formation processes involved. The syntactic components deal with functional and structural nature of Onitsha personal names at the sentential level. It indicates whether a particular name is functionally a declarative, interrogative or imperative sentence or structurally a simple, compound or complex sentence.

\section{Syntactic ANALYSIS OF OPN}

This section looks at the syntactic structure of some OPN. It looks at OPN and sentential level analysis. The names will be analysed into two broad categories: sentence function and sentence structure.

\section{A. Sentential OPN and Sentence Function}

Sentence by function is divided into declaratives, commands and questions (interrogation). The analysis of the data indicates that some OPN can be declaratives, commands, or a question.

TABLE 1

SENTENTIAL OPN WITH INTERROGATIVE FUNCTION

\begin{tabular}{|c|c|c|c|}
\hline & Formed names & Original names & Gloss \\
\hline 1 & Àkàmụ̀ònyé? & Àkàmụ̀ònyémma? & Am I better than others? \\
\hline 2 & Àfụ̀lụenū? & Àfụ̀lụ̀enūányá? & Who knows tomorrow? \\
\hline 3 & Àjụilụ̂? & Àjụ̀lụ̀chúkwúajụ̣jụ?? & Was God questioned? \\
\hline 4 & Enwèọ́nwứ? & Ōnyénwèónwú? & Who owns death? \\
\hline 5 & İbụ́zọ̀? & İbùchúkwúụ́zọ̀? & Are you above God? \\
\hline
\end{tabular}


The data in Table 1 show that many of the OPN are in interrogative sentences. The names formed are also rhetorical questions. The formed names in table 1 changed their inherent tone patterns and some segments are clipped to have the short forms. It is observed that some meanings of these names are lost after the formation.

TABLE 2

SENTENTIAL OPN WITH DECLARATIVE FUNCTION

\begin{tabular}{|l|l|l|l|}
\hline & Formed names & Original names & Gloss \\
\hline 6 & Údèmúézùè & Údèmúézùgó & My fame is complete \\
\hline 7 & Táàgbó & Táábùgbóó & It is still early \\
\hline 8 & Ónwụ́ghàlụ́ & Ónwụ́ghàlụ́ m & Death spare me \\
\hline 9 & Ńkèchí & Ńkèchúkwúnyèrè & God's gift to me. \\
\hline 10 & Éńùùmà & Éńùmàíjèm & God knows my journey. \\
\hline
\end{tabular}

The names in table 2 above are instances of OPN that have declarative structure. Placing the formed and original names side by side, it is observed that the formed names are derived through the process of truncation. In respect to the original names, the names are formed through desententialisation where sentences as observable in the gloss (egs 6-10) are compressed to serve as personal names.

TABLE 3

OPN FORMED ACCORDING TO THEIR PARTS OF SPEECH

\begin{tabular}{|c|c|c|c|c|}
\hline & Names & Formed names & Parts of speech & Gloss \\
\hline 11 & Àkụ̀ + ńné & Àkụnńnē & Noun +Noun & Mothers wealth \\
\hline 12 & Àkụ̀ + ńwátà & Àkụ̂nwátà & Noun + Noun & Young rich man \\
\hline 13 & Àkụ̀ + nwááfōr & Àkụnwááfōr & Noun +Noun & Son of the soil \\
\hline 14 & Òfú + ńné & Òfúńnē & Nominal + Noun & Siblings \\
\hline 15 & Ònyé + ọ́má & Ónyéọ́má & Participle + Adjective & Good person \\
\hline
\end{tabular}

The above examples show OPN formed with noun + noun and participle + adjective. The lexical class of the realised name is a noun. There are some names formed by compounding. Compounding is the addition of one base to another to form a new word. It is a situation where two words are combined into a morphological unit.

TABLE 4

OPN FORMED BY COMPOUNDING

\begin{tabular}{|l|l|l|l|l|}
\hline & Names & Compound names & Parts of speech & Gloss \\
\hline 16 & Chỉnwè + Okwu & Chi’nwèokwu & Noun + Noun & God decides \\
\hline 17 & Àmàlà + chukwu & Àmàlàchukwu & Noun + Noun & God's grace \\
\hline 18 & Òlì̀à + égbòó & Òlìsàegbò & Noun + Adjective & God intervene \\
\hline 19 & Àjụ̣lụ +chukwu & Àjụlụchukwu & Adjective + Noun & Did you ask God \\
\hline
\end{tabular}

The OPN by compounding retain then inherent tones when combined. Semantically, compound words have meanings and at times, their meaning, cannot be inferred from their individual meaning. The names that were formed by compounding retain their inherent tone after combination. The compound names did not affect the inherent tone of the different names combined. The analysis also identified that the compound names are exocentric compounds because they indicate a hyponym of some unexpressed semantic heads (it has no relation with each other). This shows the internal stability of the morphemes in the construction.

\section{OPN formed from participle phrases}

Òménàzụ - Born after the death of his father.

Ókwúézè - Born during the period of kingship.

Òbínwè - Belonging to the monarch.

Ónyéọmá - Good person.

The above subset of data shows de-verbal OPN showing the internal stability of the morphemes in the construction.

Chomsky and Halle (1956) assume that the internal structure of words is to be labeled, bracketing much like the internal structure of sentence. Morphemes are organized into a hierarchical, systematic, immediate constituent structure. 
Name:

(1)

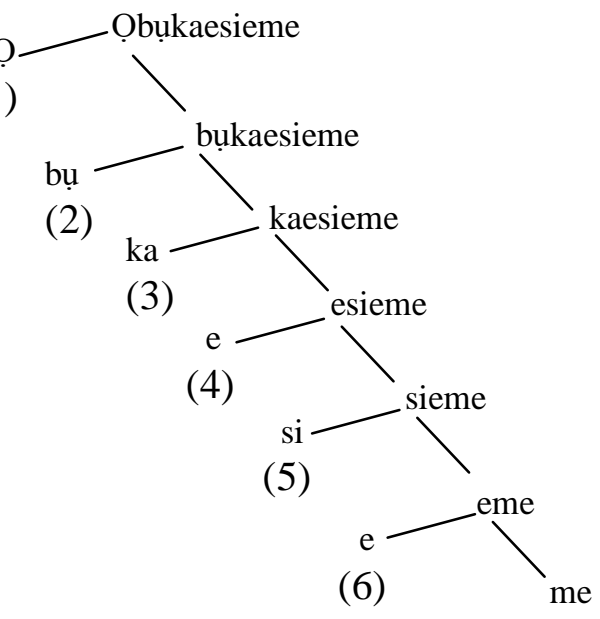

(1)

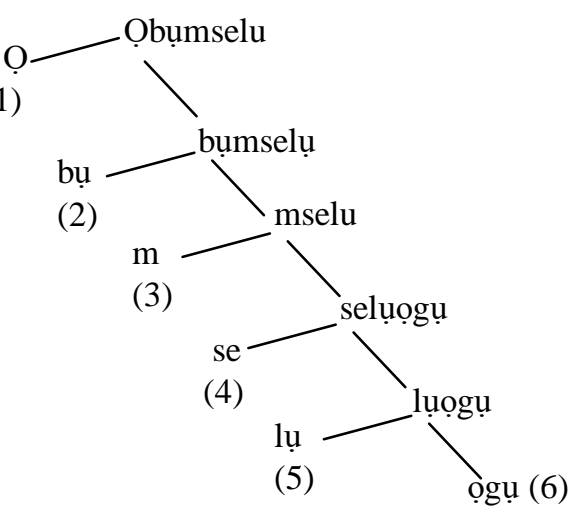

The data indicate that the arrangement of the phonemes and morphemes are fixed and compatible. Since there is a strong interface between morphology and phonology, there are some phonological processes that are involved in the formation of some OPN.

TABLE 5

Phonological Processes That ARe InVolved In The Formation Of Some OPN

\begin{tabular}{|l|l|l|l|l|}
\hline & Name & Phonological processes/type & Output & Gloss \\
\hline 20 & Olisa + egboo & Regressive assimilation & Oseegbo & God has intervened \\
\hline 21 & Olisa + emeka & Regressive assimilation & Oseemeka & God is great \\
\hline 22 & Chibụike & Elision & Chiike & God is my strength \\
\hline 23 & Emeeọdị & Regressive assimilation & Émódị & You shall reap what you sow \\
\hline
\end{tabular}

Table 5 shows that there are instances of phonological process in the word formation of OPN. Some of the morphemes undergo some phonological processes: assimilation and elision. Assimilation and possible elision are obtainable during fast speech. In many cases, Igbo people in general and Onitsha indigenes in particular elide some phonemes in names for convenience. The rationale is that it is easier to pronounce abridged version of a name than its complete form.

\section{B. Morphological Analysis of Onitsha Personal Names}

Morphology is the beginning of syntax indeed; all levels of linguistic are interconnected. Morphosyntax links morphology and syntax through morphosyntactic or simply morphological processes. It is through these interfaces that all issues about derivation, extension, and inflation are handled in human communication. This section will treat the morphological analysis of OPN; beginning with the types of morpheme and number of syllable structure of OPN.

TABLE 6

MORPHOLOGICAL ORGANISATION

\begin{tabular}{|l|l|l|l|l|l|}
\hline & Complete name (COPN) & No of morphemes & $\begin{array}{l}\text { No of } \\
\text { syllable }\end{array}$ & $\begin{array}{l}\text { Short forms names } \\
\text { (SFN) }\end{array}$ & Gloss \\
\hline 24 & Énúélūáká & 3 & 6 & Èlùaka & Life is not easy \\
\hline 25 & Ónyéméé ó dịlị à & 6 & 8 & Émódī & You will reap whatever you sow \\
\hline 26 & Mmádụàdịchíé & 4 & 7 & Ádíchíé & Compensation by god \\
\hline 27 & Íwéyíràzín'òfú & 5 & 8 & Íwénòfú & Mellow down your anger \\
\hline
\end{tabular}

\section{Morphological Structure}

In terms of Igbo tonology, morphology and syntax, Igbo nouns and verbs and nouns are better more economically classified as simple and complex. Simple nouns are - mono - morphemic, while complex nouns are bi - morphemic, tri-morphemic and multi-mophemic.

Poly-morphemic OPN - Uyanne, Anịonwu, Adaiba, Afuanya,

Bio-morphemic OPN - Chịma, Eneanya

Tri-morphemic OPN - Egodigbo, Nwadiogbu, Nwaonyeugbo

Multi - morphemic OPN - Oguejiofor, Okwuegbunam, Onyeachonam Onyeachonam

Mono - morphemic OPN - Udo, Ubili, Agụ, Agha EluIyom Ebo, Offiah, Obi. Monomorphemic are also referred to as single structures and polymorphemic as complex structures.

Generally, according to Onukawa $(1995,2000)$ Igbo personal names are derived from nouns Onitsha, beginning a dialect of Igbo language have their personal names are sentential before the application of morphological, synthactic 
and phonological rules that gives rise to the short forms. Most of OPN are polymorphemic and segmented. Sentential nominalization in the analysis of the data indicates that there are varieties of morphological components in their internal structure.

2. The Morphological Rules Applied in Formation of OPN

The morphological rules applied in forming OPN are as: clipping, compounding, vowel alteration (internal structure) affixation. In linguistics, clipping is the word formation process that consists in the reduction of a word to one part. The types of clipping in the formation of OPN are as follows:

TABLE 7

OPN THAT ARE FORMED BY FRONT CLIPPING (APHRESIS)

\begin{tabular}{|l|l|l|l|l|}
\hline & Full name & Front clipping & Formed names & Gloss \\
\hline 28 & Nwando & Ndo & Ndo & A Calm child \\
\hline 29 & Ejiroikeeme & Ejiro & Ikeme & You don't survive by struggling \\
\hline 30 & Chibuike & Chi & Buike & God is great \\
\hline 31 & Chikamma & Chi & Kamma & God is great \\
\hline
\end{tabular}

In this construction, the subject in the sentence that is combined to be a proper name is deleted. The syntactic nature of the names is formed on deletion of the front part segment. The philosophy behind the meaning of the name after the clipping process is partially or completely distorted.

TABLE 8

OPN FORMED BY BACK CLIPPING (APOCOPATION)

\begin{tabular}{|l|l|l|l|l|}
\hline & Name & Clipped segments & Short forms & Gloss \\
\hline 32 & Étúkáókwú & Ókwú & Étúká & Stressed argument \\
\hline 33 & Óbùmsèlùòù & Lùògù & Òbùmsè & Am not the cause of the fight \\
\hline 34 & Mmásíchúkwú & Chúkwú & Mmásí & Gods whish \\
\hline 35 & Sópúrúchúkwú & Chúkwú & Sópúrú & Honour God \\
\hline
\end{tabular}

The compliment and some subjects in the construction are often deleted by front clipping process. Both of them result in word reduction because a shorter word is derived or made from a longer one. In the formation of OPN names (short forms) clipping is used. Clipping as a morphological process, involves the shortening of polysyllabic words without necessary regard to derivational analogy, the shortening of personal names exemplify clipping as a synchrony one.

TABLE 9

OPN FORMED BY MEDIAL CLIPPING OR (SYNCOPE)

\begin{tabular}{|l|l|l|l|l|}
\hline & Name & Clipped segments & Short forms & Gloss \\
\hline 36 & Obi/nwere/ozo & Nwere & Obiozo & Royal palace \\
\hline 37 & Ani/nwe/onwu & New & Anionwu & All flesh must die \\
\hline 38 & A/ni/chebe & ni & Achebe & The land will protect $\mathrm{m}$ \\
\hline
\end{tabular}

TABLE 10

MIXED CLIPPING/COMPLEX

\begin{tabular}{|l|l|l|l|l|}
\hline & Name & Deleted segments & Formed names & Gloss \\
\hline 39 & Chukwukadibia/kwu, dibia/ & Kwu/dibia/kwu, dibia/ & chuka & God is greater \\
\hline 40 & Chimeeremchi & Chi/remchi & mmee & God did it for me \\
\hline 41 & Chukwudumaka & Chuk/wum & God holds me \\
\hline
\end{tabular}

\section{Desententialisation Process in Forming OPN}

The process of desententialisation is a morphological process where the subject, verb, and compliments of a clause are fused resulting in a nominal (Onukawa 1995).

TABLE 11

DESENTENTIALISATION PROCESS IN FORMING OPN $(\mathrm{S}+\mathrm{V}+\mathrm{C})$

\begin{tabular}{|l|l|l|l|l|l|}
\hline & Subject & Verb & Compliment & Fused names & Word order \\
\hline 42 & Azi & Ka & Iwe & Azikiwe & SVO \\
\hline 43 & Mba & Na & Efo & Mbanefo & SVO \\
\hline 44 & Ofor & Di & Ile & Ofordile & SVO \\
\hline 45 & Okwu & di & Nka & okwudịna & SVO \\
\hline 46 & Kwa & Ka & Ogo & Nwakaego & SVO \\
\hline 47 & Azu & bụ & ogwa & Azubuogu & SVO \\
\hline 48 & Nwa & dị & Nwadiọwa & SVO \\
\hline
\end{tabular}

\section{General Analysis of the Formation of $O P N$}

\section{Declaratives}

i. full OPN

Òlìsàjìńụ̣

$\begin{array}{lr}\text { Fòsájì } & \text { (SVO) }\end{array}$

Gloss

God is in charge of my life 


\section{$\mathrm{N} \mathrm{V} \quad \mathrm{N}$}

Ólìsà- jì-ńdù $\rightarrow 3$ morphemes

o-li-sa-ji-n - du $\rightarrow$ 5syllables

Here, there is one-word morpheme, the deletion of 'li', clipping of 'ndụ' and a change in tone.
ii. Bèlúsò
Òlìsà
Bòósà - Bŏsa
Only God knows

Adv N

belụsọ - $\quad$ Olisa $\rightarrow \quad$ 2morphemes

be-lụ-so-o-li-sa $\rightarrow$ 6syllables

The production involves deletion and we have a gliding tone after the deletion.
iii. Énwèlụmúzò
-Énwēzò
(SVO)
Do I have another one

$\mathrm{V}$ pro $\mathrm{N}$

e-nwe-lụ-ụzọ $\rightarrow 4$ morphemes

e-nwe-lụ-ụ-zọ $\rightarrow \quad$ 5syllables

In 'enwelu', we have 3 morphemes with 'nwe' as the root, 'e', as the participle maker and 'lụ' as past tense marker, hierarchically arranged. In 'Enwezọ’ we have changed in tone involving deletion of 'lụ' and 'ụ'

\section{Commands}

iv. Ùmébiélú m

$\mathrm{N} \mathrm{V}$ pro

ume-be-e-lụ-m

$\mathrm{u}-\mathrm{me}-\mathrm{be}-\mathrm{e}-\mathrm{lu}-\mathrm{m}$
The production of 'Umebee' involves the de

The production of 'Umebee' involves the deletion of 'lụ' and ' $m$ ' and the words that formed. It also retains its inherent tones.

$\begin{array}{llll}\text { v. Ábādōzìnālū } & \mathrm{m}- & \text { Àbádóm } & \text { Stop scolding me. }\end{array}$

A - bado - zi - na - lụ-m $\rightarrow$ 6morphemes

$\mathrm{A}-\mathrm{ba}-\mathrm{do}-\mathrm{zị} \mathrm{-} \mathrm{na} \mathrm{-} \mathrm{lụ} \mathrm{-} \mathrm{m} \rightarrow$ 7syllables

The formation of 'Abadom', it involves the deletion of "zinalụ' and change in tone. The morphemes in 'abadozịnalụ' are six and they are hierarchically arranged.

OPN in a complex sentence structure.

vi. Ọ́dị̂ọ̄mmātáạọ́dịéchi Ọ́dịtà Bad times will turn good tomorrow

Pro V neg adj adv prov adv

o - di - rọ - mma - taata - ọ - dị - echi $\rightarrow$ 8morphemes

o - di - rọ - m - ma - ta - a - ta - o - di - e - chi $\rightarrow 12$ syllables

'Odịta' is formed by the deletion/elision of morphemes 'rọ, mma, ọ, dị and echi and the clipping of 'taa' and it involves change in tone. The verb 'dịrọ', 'ro' is a negative marker. The new formed name lost some important information about the name from the deleted segments.

OPN in the form of simple sentences

vii. Ázịkà/ ka íwé

viii. Ò̀fọ́dị ìle

ix. Ńwádị

\section{Complex Sentence}

x. [Ọ bụrụnaụwaekwe, m ga-adị],

\section{GLOSS}

Youths are easily enraged.

Equity is justice

It is good to have different sex

\section{Gloss}

$\left\{\begin{array}{l}\text { ndụ } \\ \text { mma }\end{array}\right\} \begin{array}{r}\text { I will the survive despite tribulation } \\ \text { paragmatic relationship }\end{array}$

The name contains 2 verbs; hence, it is a complex relationship structure and can take various complements which are in a paradigmatic relationship. The parenthesised sentence is the conditional sentence while the other part is the subordinate clause. The name shows some elements of persecution around the bearer of the name.

xi. Name

Formed OPN

Glosses 
Ó oníànyanwà nà - énìlúónwé/yā - Óníànwà $\quad$ Who digs a pit will fall inside it

Complex sentence involves the deletion of the subordinate clause for the production of 'Óníanwà. The meaning of the subordinate clause depends on the main clause.

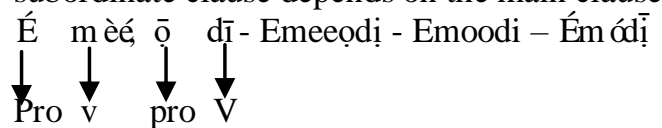

This is also a complex sentence and the end product 'Emodi', was formed by the assimilation (Regressive) and deletion with tone change.

\section{Compounds}

xii. Chí + nwé + ókwú Chínwèókwú Chínwŏkwú

It involves compounding, regressive assimilation and finally, deletion and the end product Chinwokwu has a gliding tone.

xiii. Òlìsà + égbògó + ògù - Olisaegbo (ọgụ) - Oliseeegbo - Òlìségbò

Here, 3 words were joined -2 noun and 1 verb. 'Ogụ' was clipped with Olisaegbo left. 'e' assimilated 'a' and finally, one 'e' was deleted.

TABLE 12

OPN NAME FORMED FROM DIFFERENT PARTS OF SPEECH

\begin{tabular}{|c|l|l|l|}
\hline From nouns & Verb & Adjective in function & Numerals \\
\hline a. Ubuni & Obanye & Ụzọamaka & Ofunne \\
\hline b. Uyanne & Ojekwu & Okechukwu & Adịbụa \\
\hline c. Uzọnịcha & Onyalụ & Obinwa & \\
\hline
\end{tabular}

Most OPN that are formed from verb roots have affixes attached to them.

Obanye - o $/ \mathrm{ba} /$ nye. o is the prefix, -ba is the verb root and nye is the suffix.

Ojekwe - o/je/kwe. o- is prefix,-je is the verb root and kwe is the suffix.

\section{CONCLUSION}

This paper has shown the morphological and syntactic structure of Onitsha personal. From the data analysis and discussion, it has been observed that some of the names change their inherent tones when the rules of word formation are applied, while some drop the subject in the construction when front clipping rule is applied to the name that are sentential. The clipping takes away some important information in the name resulting in the loss of the philosophy behind the name. In addition, the internal structure of the names analysed show the arrangement of the phoneme and morphemes are fixed and compatible. The hierarchical organization of the morpheme that is segmented to form the names is also shown the analysis. Some OPN syntactically function as declaratives, commands and interrogative. In terms of size, length or shape the morpheme are mostly polymorphemic and polysyllabic showing varieties of morphological components in the internal structure. Most derivation takes place with verbal roots while some undergoing some phonological process thereby changing their forms.

\section{REFERENCES}

[1] Agyekum, K. (2006). The sociolinguistic of Akan personal names. Nordic Journal of African Studies, 15(2), 206235.

[2] Ahamefula, N. O., Odii, B. C., Udechukwu, C. N., Ezemoka, A., Aboh, S. C., Okoye, L. C., Ozioko, E. \& Nwachukwu, A. P. (2019). Intercultural communication and international cohesion: A study of Chinese and Igbo names exchange phenomenon. Igbo scholars International Journal of Igbo Scholars Forum, Nigeria, 12(1), 47-65.

[3] Akinola, O. A. (2014). Communicative role of Yorùbá names. International Journal on Studies in English Language and Literature (IJSELL), 2(9), 65-72.

[4] Anderson, S.R. (1992). A-morphous morphology. Cambridge: Cambridge University Press.

[5] Aronoff, M. (1976). Word formation in generative grammar. Cambridge: MIT Press.

[6] Batoma, A. (2006). African ethnonyms and topononyms: An annotated bibliography. Retrieved from http://lir.ulowa.edu/ejab/10/10/1ss1/1 on 20/08/2018.

[7] Bosah, B.I. (1975). Groundwork of the history and culture of Onitsha. Onitsha: Etukokwu Printing Press

[8] Chomsky (1956). Three models for description of language. Transaction on Information Theory, 2, 113-124.

[9] Chomsky, N. (1970). Remarks on Nominalization. In R. Jacobs \& P. Rosenbaum (Eds.), Readings in English transformational grammar. Waltham Massachusetts: Gin and Company.

[10] Crystal, D. (1985). A dictionary of linguistics and phonetics (2nd ed.). New York: D.C. Heath and Company.

[11] Eze, A. N., Aboh, S. C. \& Eze, D. E. (2020). Linguistic formation patterns of anglicised traditional Yorùbá anthroponyms, Southern African Linguistics and Applied Language Studies, 38(4), 282-292.

[12] Halle, M. (1973). Prolegomena to a theory of word-formation. Linguistic Inquiry, 4, 3-16.

[13] Haspelmath, Martin. (2008). Loanword typology: Steps toward a systematic cross-linguistic study of lexical borrowability. In T. 
Stolz, D. Bakker \& R. Salas Palom, (eds.), Aspects of language contact: New theoretical, methodological and empirical findings with special focus on Romancisation processes, 43-62. Berlin: Mouton de Gruyter.

[14] Ikotun, R. O. (2013). New trends in Yorùbá personal names among Yorùbá christians. Linguistik Online, 59(2/13), 67-85.

[15] Marchand, H. (1969). The categories and types of present-day: English wood formation. Munchen: C.H. Beck'sche Verlagsbuchhandlung.

[16] Mbhele, M. (2006). Sesotho non-proprials as phrases. Tsebo-journal of Research and Creative Writing, 1(1), 31-41.

[17] Onukawa, M. (1995). A Re-analysis of the So Called Igbò De-sentential Nominals. In N. Emenanjo \& O. Ndimele (Eds.), Issues in African Languages and Linguistics: Essays in Honour of K Williamson, 266-278. Aba: NINLAN.

[18] Onukawa, M. C. (2000). The Chi concept in Igbo gender naming. Africa, 70(1), 107-117.

[19] Yule, G. (2020). The study of language (7th ed.). Cambridge: Cambridge University Press.

Obiageli C. Ezeudo was born in Onitsha, Anambra State on 1st August. She has Bachelor of Arts Degree, Master of Arts Degree and $\mathrm{PhD}$ in Linguistics at the University of Nigeria, Nsukka. Obiageli specialises in Psycholinguistics and Applied Linguistics. 108 .

She has co-published "Sound symbolism in Igbo: A Magnus approach", Journal of Linguistic Association of Nigeria, 20(2), 104-

Dr. Ezeudo is a member of Pragmatics Association of Nigeria, and Linguistic Association of Nigeria.

Sopuruchi C. Aboh was born in Aba, Abia State on 20th November. He had his Bachelor of Arts Degree and Master of Arts Degree in Linguistics at the University of Nigeria, Nsukka. Sopuruchi specialises in Sociolinguistics and Pragmatics.

He has published some articles including: "The ideology of post-truth in Nigerian cities: A discourse historical analysis", Journal of Linguistic Association of Nigeria, 22(1), 64-78 and "A comparative analysis of lexical prepositions in the Ibibio and Igbo languages", Macrolinguistics, 6(9), 36-45.

Mr. Aboh is a member of Pragmatics Association of Nigeria, Nigeria Ecolinguistics Association, and Nigerian Institute of Translators and Interpreters.

Kalu M. Idika is a PhD student in the Department of Linguistics and Nigerian Languages, University of Nigeria, Nsukka. He holds Bachelor of Arts Degree and Master of Arts Degree in Linguistics. Obiageli specialises in Cognitive Semantics and Applied Linguistics.

He has co-published "Sound symbolism in Igbo: A Magnus approach", Journal of Linguistic Association of Nigeria, 20(2), 104108.

Mr. Idika is a member of Linguistic Association of Nigeria. 